\title{
Acculturation of islamic culture as a symbol of siraman rituals in java traditional wedding
}

\author{
Suyadi \\ Universitas Islam Negeri Walisongo Semarang, Indonesia \\ suyadisekawan4@gmail.com \\ Ahmad Fikri Sabiq \\ Institut Agama Islam Negeri Salatiga, Indonesia \\ ahmadfikrisabiq@gmail.com
}

\begin{abstract}
The purpose of this study was to determine the acculturation of Islam and local culture in the Javanese traditional wedding ceremony. This research uses a qualitative approach. Collecting data by interview, observation, and documentation. The location of this research is in Kedungjati, Grobogan. Data analysis using the semiotic theory of Roland Barthes. The result of this research is that the ritual of siraman in Javanese traditional wedding in Kedungjati has connotation, denotation, and myth meaning as in the semiotic analysis of Roland Barthes. The siraman ritual has sixteen stages of the process, namely the installation of bleketepe, sungkeman, ngracik toyo, praying, siraman, sesuci, pecah kendhi pratolo, pondhongan or gendongan, ganti busana, pangkas rikma, tanam rikma, pagas tumpeng, Dulang pungkasan, adol dawet, itung duwit, and simpen pedaringan.
\end{abstract}

Keyword: Islamic Acculturation; Culture; Semiotic Analysis.

\begin{abstract}
Abstrak
Tujuan dari penelitian ini adalah untuk mengetahui akulturasi Islam dan budaya lokal pada ritual siraman pernikahan adat Jawa. Penelitian ini dengan pendekatan kualitatif. Pengumpulan data dengan wawancara, observasi, dan dokumentasi. Lokasi penelitian ini di Kedungjati, Grobogan. Analisis data dengan teori semiotik Roland Barthes. Hasil dari penelitian ini adalah bahwa
\end{abstract}


ritual siraman pada pernikahan adat Jawa di Kedungjati memiliki makna konotasi, denotasi dan mitos sebagaimana dalam analisis semiotik dari Roland Barthes. Ritual siraman memiliki enam belas tahapan proses, yaitu pemasangan bleketepe, sungkeman, ngracik toyo, berdoa, siraman, sesuci, pecah kendhi pratolo, pondhongan atau gendongan, ganti busana, pangkas rekma, tanam rikma, pagas tumpeng, dulangan pungkasan, adol dawet, itung duwit, dan simpen pedaringan.

Kata Kunci: Akulturasi Islam; Budaya; Analisis Semiotik.

ACCEPTED : October $4^{\text {th }} 2020$ REVIEWED: December $4^{\text {th }} 2020$ PUBLISHED: February $13^{\text {th }} 2021$.

\section{Introduction}

Humans cannot be separated from the cultural values and religious teachings that they believe so that the tension between religious doctrine and local cultural values cannot be avoided. Tensions occur when local religions and cultures insist on maintaining their respective existence. Religion is absolute because it comes from God and comes from the Qur'an and Hadith. Both sources are transcendent from social reality (Azra, 1999). Meanwhile, cultural values, traditions, and customs are relative because human products are sometimes not in harmony with religious teachings. Religion provides life guidance to humans about divinity, and it is often not fully understood by all humans because the conception given by God is conveyed with symbols (Herusatoto, 1997).

Siraman nganten Javanese custom is a sacred ceremony that contains expressions about customs, attitudes of the soul, nature of mind, and spiritual views that originate from Javanese culture. This sacred ceremonial ritual is one of the cultural treasures of the region which contains very deep Javanese ethical values. These ethical values serve as a guide or basis for the virtue of the Javanese moral character of Javanese culture.

Traditional society uses certain rituals in siraman, such as installing bleketepe, sungkeman, ngracik toya seven sources, doing prayer, siraman, ablution or sesuci, breaking kendhi from the ground, pondhongan or carrying, changing clothes, cutting rekma, grave rikma, Pagas tumpeng, Dulang pungkasan, sade dawet and counting the results of adol dawet, giving offerings and various other ceremonies (Irmawati, 2013; Sutawijaya, 1990). So that the local tradition or culture is a living tool to serve humans. 
Meanwhile, Islam is a universal religion that can apply to any group, anyone, anytime. Because the influence of locality or tradition in ethnic groups is difficult to avoid, whether it is recognized or not recognized in Muslim community life.

However, the phenomenon that has occurred recently is that the Javanese traditional Javanese ritual of siraman nganten is only carried out for reasons according to tradition. because they feel that someone is a member of their community to increase family prestige. Even though dealing with local culture and Islam. The universality of Islam will not be canceled so that this is an indication of the difference between one place, one region, and one country from another which does not become an obstacle in realizing Islamic goals which remain as guidelines in aspects of life.

The combination of Islam and local culture brings about the religious reality of applying general and universal principles of religion regarding diversity in its technicalities. Islam entered Indonesia not because society lacks culture. In practice, culture is accommodated and adopted and Islamized. The spread of Islam in the archipelago has three patterns, namely integrative, dialogic, and a combination of integrative and dialogical (Hadi, 2006). Islam first entered the land of Java in the Demak area (Susilo, 2019). So that the influence in Demak is the influence of Islam which is the area of the Islamic kingdom for the first time according to the theory of Mecca in the $7^{\text {th }}$ century. We need to know that there are differences between Javanese and Islamic customs.

The process of entering Islam is carried out in various ways, namely marriage, trade, politics, education, and culture. The entry of Islam to Indonesia cannot be separated from the role of walisongo (Anasom, 2004). They spread Islam peacefully throughout the country with polite and peaceful methods. This has led to the acculturation of Islam and culture in Indonesia in accordance with the architecture of the Demak Mosque which is evidence of the development of Islamic culture (Ngationo, 2018). Religion and Islamic culture that entered Indonesia because they were easily accepted by the community, influenced the original Indonesian culture, causing acculturation. The acculturation of Islam and culture occurs in several ways, for example, architecture, carving, puppet art, births, weddings, funerals, and literary arts such as 
chronicles, saga, and others (Susilo, 2019). The acculturation of Islam and Javanese culture can also be seen in traditional rituals, especially siraman. The various results of the acculturation of Islam and Javanese local culture are used as a means for planting Islamic values into the life of Javanese people (Aziz, 2013).

The existence of the transformation of local culture, especially Java and its relation to religion, is an acculturation of Islam and Javanese local culture, where there are differences and similarities with each other. Every culture has a local culture (peculiarities), the values possessed by this local culture can then become local indigenous which is carried out by the community. This also applies to Javanese ethnic communities who have a distinctive culture and uphold the characteristics and local noble values of their culture. The acculturation of Islam and local culture is a form of cultural preservation that will gradually disappear. The process of preserving culture will be justified as long as it does not contradict Islamic law or in accordance with the legal basis of the legitimacy of syara 'in the form of urf and maslahah.

A process that does not eliminate existing customs creates a mix of cultural diversity. Muhazzab Said said that Islam does not perceive plurality as short of split potentially leading to the disaster that might bring down the foundations of unity in human life (Said, 2015). Cultural values and religious teachings are believed to be inseparable from human life so that the tension between religious doctrine and local cultural values cannot be avoided. Tensions occur when local religions and cultures insist on maintaining their respective existence. Religion is absolute because it comes from God which comes from the Qur'an and Hadith which is transcendent from social reality (Azra, 1999).

Rituals that combine Islam and local culture can be said to be two sides of a coin that cannot be separated. The two together determine the value of the currency. On the one hand, Islam that came and developed in Java was influenced by the existing culture or Javanese culture that existed and developed earlier. While on the other hand, Javanese culture (rituals) was increasingly enriched by Islamic treasures (Prabowo, 2003). Thus, the combination of the two shows or gives birth to a new culture that has distinctive characteristics as a syncretic culture. Although Islam 
with all of its teachings does not try to form a monolithic culture. It is proven that in an area with other regions that do not always have uniform cultural products, Islam as religious teaching continues to understand the existing culture with the existence of Islam. Finally, both religion and culture which are more dominant will form a new culture (Widiana, 2015).

Javanese life is very ceremonial (Roqib, 2007). They always want to formalize a situation through ceremony and ritual. Javanese ceremonies are related to the human life cycle (Koentjaraningrat, 2000). These ceremonial activities are carried out to preserve a local culture to achieve a goal (Mulder, 1986). These ceremonies include customs that are sacred both regarding the intention, purpose, form of the ceremony, ceremonial equipment (ubarampe), and the procedures for the implementation (Bratasiswara, 2000). So that when it comes to carrying out the ceremony, it requires thorough preparation and even seems complicated or complicated (Irmawati, 2013).

Studying and understanding the meaning and meaning of Javanese culture is like entering a forest of lush symbols which is full of challenges, uniqueness and at the same time a tantalizing attraction (Susanto, 1979). Many philosophies that mean philosophical in Javanese culture still have a pulse of actuality. Not all Javanese philosophies are outdated or ancient, which are often popular with the words jadul (ancient times) or deso. But if it is done with re-actualization, there will be clarity of meaning, meaning, and purpose. The lush symbolic forest full of pseudo signs, antique, artistic, which has aesthetic and ethical values cannot be grasped its meaning and meaning if it is not disclosed comprehensively. It may even lead to a fragmentary understanding or only be caught in the outer shell.

Many people see and perform the traditional siraman ceremony at the wedding ceremony procession. However, not everyone understands the meaning, meaning, and purpose of the ritual even though it is full of symbols that need to be understood. According to the theory introduced by Roland Barthes, semiotic theory consists of connotation, denotation, and myth (Barthes, 1972). Each symbol in the sequence of implementation and its tools is full of meaning. Therefore, a study must 
be carried out so that the meanings and symbols become clear about their meaning, purpose, and purpose. The benefit is that the siraman ceremony is not only used as a symbol of pomp for those who have a desire and social status but also in order to preserve customs (Muti'ah, 2009).

The process of acculturation of local culture with Islamic teachings does not appear to be in line with the principles of religious teachings. But this long historical journey was able to provide a nation's cultural wealth, even to create diversity and become a means of unifying the nation (Baidhawy, 2002). Therefore, culture is the result of human work and habits, so that humans themselves can accept, reject, or change the culture.

One form of acculturation of Islam and local culture is the holding of a siraman ceremony when having a wedding. The siraman ceremony, which contains philosophical and religious (religious) values, regardless of the pros and cons, shirk or non-shirk, is a fact that this exists in Javanese society and is carried out by them. This is consistent with what Susanne K. Langer said that one of the basic human needs is the need for symbolization or the use of symbols (Hayakawa, 1974).

In order to reveal the symbolic meaning contained in this siraman ceremony, a research study is needed. This is so that the people who carry out this ceremony understand what is being done. This study also parses the acculturation that occurs between Islamic teachings and Javanese local culture in the siraman ritual.

\section{Research Method}

The approach and type of this research is descriptive qualitative research. Qualitative research aims to understand the phenomena experienced by research subjects, in this case, namely Javanese traditional marriage which is communication behavior, motivation, holistically using descriptions in the form of words and language, in a special natural context and by utilizing various natural methods (Moelong, 2009). Researchers researched by observing the activity of siraman in Javanese traditional weddings which were held in the Kedungjati sub-district.

The research location chosen in this study is in the Kedungjati subdistrict, Grobogan district. This location was chosen because geographically it is located between Demak, which is known as the 
history of the development of the Islamic kingdom which until now is thick with its Islamic beliefs, with the areas of Solo and Yogyakarta which are famous for their Javanese traditional development to date.

This study uses several sources, namely primary data sources and secondary data sources (Arikunto, 2002). Primary data sources are the person is considered to know the most about the problem to be studied. Secondary data sources are books, internet or online, newspapers, documents or archives, and other library materials that have relevance to this research in order to enrich the data of this research.

Collecting data in this study were interviews, observation, and documentation. Interviews were used to obtain data on the Javanese traditional marriage process. Meanwhile, the observation is used by the researcher directly to the data sources that exist in the siraman process in Javanese traditional weddings in the Kedungjati sub-district. And documentation is used to collect documents that are used as archives in this study

The data analysis method that the writer uses is a descriptive qualitative data analysis method. The point is the analysis process which will be based on descriptive and qualitative principles. The descriptive principle is that the analysis process is carried out on all data that has been obtained, processed, and then the results of the analysis are presented as a whole.

The theory used to analyze is the acculturation of Islam and local culture about siraman then analyzes it with indexicality analysis. Indexicality is the relationship between word communication, behavior, and others in its context.

In this study, the validity of the data was tested using triangulation techniques. Triangulation technique is the technique most widely used for examination through other sources for comparison purposes in order to improve the quality of the assessment. Triangulation is a technique of checking the credibility criteria or a way to increase the validity of data in qualitative research.

\section{Results and Discussion}

Acculturation is a concept to describe the long process of meeting two or more values belonging to individuals, groups, and society. The 
emergence of rejection of new values must be understood as part of the community's love for old (local) values. It is a learning process to understand the new values that are coming. In this condition, it is not appropriate to use a win or lose claim between Islam and local culture.

Islam is essentially a religion that loves peace which always upholds diversity or multicultural values (Hanafi, 2016). Living in a society, will be very harmonious and colored by the culture it has. So that Islam will have various variants according to the cultural heterogeneity that exists in society. This condition will continually experience ups and downs, whether Islam will color the culture more or vice versa culture will color Islam.

The notion of culture in cultural anthropology is in line with Daniel's suggestion that "cultural anthropology is the study of both specific contemporary human societies and the underlying patterns of human culture. Often of the terms 'social anthropology' and 'cultural anthropology' are used interchangeably, both combine the description of particular societies with the effort to understand the reasons for similarities and differences among them. These latter aspects of cultural anthropology are known as ethnography and ethnology, respectively" (Bates, 1990).

It is different, according to Stanley, that culture in life is a social tradition in living life. "Culture is the learned, socially acquired traditions and lifestyles of the members of society, including their patterned, repetitive ways of thinking, feeling, and acting" (Baran, 2010). Cultural style is influenced by religion and conversely, the understanding of religion is influenced by the level of culture (in this case intelligence). Geertz defines culture and religion as a pattern of rules, guidelines, and instructions for controlling human behavior (Syam, 2007).

Umar Kayam defines culture as a process understood as a dialectical community effort in answering and filling the spaces in every problem and challenge it faces. Thus, culture is something restless, which is constantly moving dynamically and short. This dialectical nature implies the existence of a "continuum", a continuity of history and behavior in human life (Ruben, 2014). 
The definition of culture according to Ki Narto Sabdo is angenangen of beauty (Amin, 2002). In religious life, the tendency to modify Islam with Javanese culture has given birth to various new products, especially in the results of the interrelation between Javanese and Islamic cultural values on ritual aspects. In the teachings of Islam in general, ritualistic activities are something that must be done for its adherents. This ritualistic activity includes various forms of worship, as encapsulated in the pillars of Islam. The essence of the activity is a prayer addressed to Allah SWT to achieve His pleasure, the purpose of the ritual for the Javanese community is nothing but to seek blessings, which Javanese usually use ngalap blessing (hoping to get mercy, safety, and happiness from the ritual). The ceremony or ritual in its implementation contains something sacred, holy, and mystical.

Mystical, this occurs in humans or objects that have a power that is believed to be more powerful than humans or other objects (Syam, 2005). For example, there are human figures who have advantages in certain supernatural fields (Wali). The Javanese mystique is a manifestation of the Javanese religion. Javanese religion is an accumulation of Javanese community religious practices. In Javanese Geertz's view, the Javanese religion has three variations, namely Javanese abangan, santri, and priyayi.

In this religious practice, some people believe in syncretic influences with other religions, at least Hinduism, Buddhism, and Islam. On the other hand, some believe puritanically that the Javanese mystique belongs to the Javanese people that existed before other influences. Each of these assumptions has reasonable reasons. The essence of the Javanese religion is the worship of the ancestors or ancestors. This worship is manifested through mystical and immortal attitudes. Although they externally worship spirits, their essence remains God-centered. So, the Javanese religion which is based on mystical attitudes and behavior remains centralized to God (Endraswara, 2006).

Religion, in Javanese expression, is like ageman or dress. The spirit and religious teachings are integrated with the social activities of the community. The expressions of diversity that are most easily seen by children are ritual activities such as prayer, recitation, and fasting. 
However, as an adult, he realized that religion and culture are different but mutually supportive like a relationship between spirit and body. Through local culture and traditions, religious teachings are expressed so that what is called local genius (local genius) or local wisdom (local wisdom) emerged (Hidayat, 2012).

The Hindu-Buddhist influence did not disappear but was strengthened by Islam. In Javanese society, the appreciation of transcendent values is so real. The implementation of traditional ceremonies has a very important meaning for the members of the community concerned. This is due to its function as a reinforcement of existing cultural norms or values in society. For Javanese people, life is full of ceremonies related to the circle of human life from its existence in the mother's stomach until her death, or also ceremonies related to the activities of daily life in earning a living, especially for farmers, traders, fishermen and so on (Amin, 2002).

The ceremonies were originally carried out in order to ward off bad influences that would endanger human survival, by making offerings or a kind of sacrifice which were presented to certain magical powers. Of course with the ceremony, the performer of the ceremony hopes to live in a safe condition (Purwadi, 2004).

According to Professor Veth, followers of Islam who are the largest group in Java do not entirely embrace this religion purely. Veth classifies Muslims into four groups: (1) Muslims who still hold a mixture of Brahma and Buddhist beliefs, (2) Islamists who have magical beliefs and dualism, (3) Islamists who have animism, (4) Muslims who practice pure Islamic teachings. By Veth, the first three groups are classified as being Javanese, and until now the Javanese teachings of Kejawen are still widely adhered to by Muslims in Java (Kholil, 2008).

Siraman according to Hariwijaya comes from the word siram which means showering with the shower. The siraman ritual is performed by the Javanese community, which is a cultural ceremony performed by a bride and groom before carrying out consent and qabul (Hariwijaya, 2004). Siraman is a water bath ceremony or ritual that is given flowers for the prospective bride and groom before carrying out the wedding ceremony. 
Siraman is also called adus kembang (flower bath) because the water used is mixed with sritaman flower (Pringgawidagda, 2006).

Adus kembang, also known as ados pamor, means the combination of water used is usually an odd number (five or seven springs) which are made into one holy water. Siraman is the beginning of the opening of the pamor (aura) that is the first or the beginning so that the face of the bride and groom can shine (Pringgawidagda, 2006). Furthermore, semiotics is a science or analytical method for studying signs. Signs are tools that we use in trying to find a way in this world, among humans, and together with humans for the balance of life and nature. Semiotics aims to study how humanity interprets things (things). It means that objects not only carry information, in which case they want to communicate conveying messages and invitations but also constitute a structured system of signs.

Semiotics is the study of signs in human life. This means that everything present in our lives is seen as a sign, that is, something that we must give meaning. Ferdinand de Saussure saw signs as a meeting between form and meaning. Ferdinand uses the term significant (marker) for the form aspect of a sign, and signifie (marker) for the aspect of its meaning. Thus, what is in our lives is seen as a "form" which has a certain "meaning" but is not personal but social, that is, it is based on social "conventions".

Roland Barthes himself was born in Chevourg in 1915 and died in Paris in 1980 from a Protestant family in Cherbourg and grew up in Bayonne, a small town near the Atlantic coast in southwest France. He is a semiotics expert who developed studies that previously had a thick color of structuralism to the semiotics of texts. Semiotics not only examines the signifier and signified, but also the overall relationship. The text that Roland Barthes refers to is in a broad sense. The text does not only mean that it deals with linguistic aspects. Semiotics can examine texts in which signs are coded in a system. Thus, semiotics can examine various texts such as news, films, advertisements, fashion, fiction, poetry, and drama (Sobur, 2003).

Barthes' semiotic theory is almost literally derived from de Saussure's theory of language. Roland Barthes stated that language is a sign system 
that reflects the assumptions of a certain society at a certain time. Furthermore, Barthes uses the significant-signifies theory which is developed into a theory of meta-language and connotations. The term significant becomes expression (E) and signifies becomes content (C). However, Barthes said that between $\mathrm{E}$ and $\mathrm{C}$ there must be a certain relation (R), thus forming a sign (Sign). This concept of relation makes the theory of sign more likely to develop because the relation is defined by the user of the sign. According to Barthes, expressions can develop and form new signs, so that there is more than one with the same content. This development is referred to as a multilingual symptom and forms what is called synonymy.

As Saussure's view, Barthes also believes that the relationship between marker and marker is not formed naturally, but is arbitrary. If Saussure only emphasizes marking at the denotative level, Roland Barthes perfected the semiotic Saussure by developing a marking system at the connotative level. Barthes also saw another aspect of signification, namely "myth" which marks a society (Budiman, 2011).

Barthes presents the concept of denotation, connotation, and myth as the key to his analysis. Barthes uses a much simpler version when discussing the signing model (Wibowo, 2013). Barthes extensively discusses what is often referred to as the second level meaning system (Two order significations) which is built on the other systems that have been there before. Some points about the meaning of symbols are as follows: First, the first level meaning system (denotative). In a general sense according to Sobur, denotation is usually understood as a literal meaning, the "real" meaning, sometimes even being confused with a reference or reference. This process of significance which is traditionally referred to as denotation usually refers to the use of language with a meaning that is in accordance with what is spoken. However, in Roland Barthes' semiotics, denotation is a system of first-level significance. In this case, denotation is more associated with closed meaning. Denotation is a relationship that is used in the first level of a word which freely plays an important role in speech. The meaning of denotation is direct, namely, the special meaning contained in a sign and essence can be called a 
description of a sign. For example, in the dictionary, the word jasmine means "a kind of flower" (Sobur, 2003).

Second, the second level of the meaning system (connotative). The connotation is the term Barthes uses to denote the second stage of significance. This describes the interactions that occur when the sign meets the feelings or emotions of the reader and the values of the culture. The connotation has a subjective or at least intersubjective meaning. In other words, denotation is what the sign describes to an object, while the meaning of the connotation is how to describe it. The connotation works on a subjective level so that its presence is not recognized. Readers easily read connotative meanings as denotative facts.

In Barthes' framework, the connotation is identical to the operation of ideology, which he calls myth and serves to reveal and provide justification for the dominant values prevailing in a certain period (Zoest, 1991). The term connotation is used by Barthes to denote the second stage of the system of significance. The word connotation itself comes from the Latin connotate, "to be a sign" and leads to cultural meanings that are separate/different from other words or forms of communication. The connotative meaning is a combination of the denotative meaning with all the images, memories, and feelings that are generated when our senses touch with signs.

(Pringgawidagda, 2006)The connotative sign not only has an additional meaning but also contains the two parts of the denotative sign that underlie its existence. This addition is Barthes' valuable contribution to his refinement of the semiotic Saussure, which only stops at the marking at the first layer or the denotative level alone. By opening up this area of connotative meaning, the reader of the text can understand the use of figurative and metaphorical language styles that are impossible at the denotative level.

Third, myth, which in Barthes's view differs from the concept of myth in a general sense. Barthes argues that myth is a language, so myth is a communication system and myth is a message. In his elaboration, he argues that myth in this particular sense is the development of connotations. The connotation that has long been formed in society is a myth. In Hoed, Barthes also said that myth is a semiological system, 
namely a system of signs that are interpreted by humans. Myth can be said to be a product of social class which already has domination. Barthes's myth in itself is different from the myth that we consider superstitious, absurd, ahistorical, etc., but the myth according to Barthes is a person's type of speech.

The characteristics of myth according to Roland Barthes are: First, Deformative. Barthes applies the Saussure elements to form (signifier), concept (signified). Which adds significance which is the result of the relationship between the two elements. Signification is what becomes a myth that distorts meaning so that it no longer refers to the real reality. In myth, form and concept must be stated. Myths are not hidden, they serve to distort, not to dispel. Thus, the form is developed through a linear (in language) or a multidimensional context (in the figure). Distortion is only possible if the meaning of the myth is contained in the form.

Second, intentional. Myth is a type of discourse that is expressed intentionally. Myth is rooted in historical concepts. The reader must discover the myth. Third, motivation. Language is arbitrary, but it has limits, for example through affixation, derivative words are formed: readread-read-read-read. On the other hand, the meaning of myth is not arbitrary, there are always motivations and analogies. The interpreter can select the motivation from several possible motivations. Myth plays on the analogy between meaning and form. This analogy is not natural, but historical.

The examples of myth in the view of Roland Barthes, according to Barthes, in the expression of the first layer means, an alcoholic drink made from grapes. However, in the second layer, wine is interpreted as a characteristic of the French which the world community gives to this type of drink. People always think of wine, yes France, even though many other countries also produce similar drinks. With this example, Barthes wants to show that the symptoms of culture can acquire connotations according to the point of view of society. If the connotation is established, it becomes a myth. Meanwhile, the established myth will become an ideology.

Barthes suggests five types of code that commonly operate in a text. Roland Barthes classifies these codes, namely hermeneutical code, 
semantic code, symbolic code, narrative code, and cultural code or cultural code. Hermeneutic code, namely the articulation of various ways of questioning, puzzles, responses, enigma, postponement of answers, finally leading to answers. Or in other words, hermeneutic code is related to puzzles that arise in a discourse. Who are they? What happened? What were the obstacles? How is the goal? One answer delays the other.

The siraman ritual that exists in Javanese traditional weddings has various sequences of activities. Each activity in this series of siraman rituals has its meaning and purpose. Furthermore, the authors conducted a semiotic analysis and acculturation of Islam and local culture contained in the siraman ritual activities at traditional Javanese weddings. The semiotic analysis uses the theory of Rolland Barters, which consists of denotation, connotation, and myth. Denotation is a system of first-level meaning Signifier-signified and sign, namely the true meaning. The point is in this siraman ritual, denotation meaning analysis is aimed at activities carried out in siraman rituals.

Meanwhile, the meaning of connotation is the second meaning, that is, in other words, connotation contains non-real meaning and tends to exaggerate. Meanwhile, myth is a communication system that develops in a society that has a message, purpose, hope, and prayer in it. In other words, myth is the result of a combination of denotations and connotations in the form of beliefs that develop in society according to their beliefs. The combination of denotational meaning, connotation, and myth is the value of acculturation between Islam and the local culture, namely Java.

The explanation of the semiotic meaning of Roland Barthest and Islamic acculturation can be explained based on the results of an interview with Kyai Taufiqurrohman as a religious figure who has a profession as a preacher and has also been a preacher in the performance of the late mastermind, Entus Susmono said that siraman is in accordance with the command of Islam "Javanese culture It has become a habit, but from the Islamic element, it provides a reference for every act of goodness or practice it should be started from clean or clean or as sacred or toharoh. In Islam, if you want to pray, you should perform ablution or after the junub (husband and wife gather) you should take a 
big bath as an Islamic discourse. The ritual journey for the bride and groom should not be far from the Islamic concept. The bride and groom will end their bachelor's single period or occupy the Dampar Kencono or stop there and have to clean up first." (Interview with Taufik) The implementation of siraman is the beginning of the marriage so that the siraman is an opening ritual or cleansing the bride and groom both physically and mentally.

Meanwhile, according to Triyanto, who is a humanist and also works as a puppeteer, that in siraman has a sequence and meaning, namely as follows "The sequence of the siraman ritual is the installation of bleketepe, sungkeman, ngracik toya seven sources, performing prayers, siraman, ablution. or sesuci, breaking kendhi from the ground, pondhongan or carrying, changing clothes, trimming rekma, grave rikma, pagas tumpeng, Dulang pungkasan, sade dawet, and counting the results of adol dawet."

Based on this explanation, it is known that the siraman ritual does not only pour water on the bride and groom, but there are other processes carried out before and after this watering. First, the installation of bleketepe, which is woven young coconut leaves (janur), which is installed above the entrance, called tarub. Tarub itself is a gate that is installed at the entrance and is made of whole plantain trees.

Triyanto said that "this bleketepe has the meaning of opening the" hambuko wiwaraning hall wismo "the door to receive guests and pick up guests as a sign that they are having a reception work. Furthermore, Sugiyati, bridal make-up, added that "bleketepe is installed by the father of the groom or woman who has a job (hajat)." February, as the host of the wedding ceremony and also a community leader, added that "The father of the bride and groom put up a bleketepe, assisted by a makeup artist."

The denotation main of bleketepe is made of woven coconut. while the connotation of bleketepe is the opening of a wedding ceremony. And the mythical meaning of this bleketepe is to open the door to sustenance. In Islam, the bleketepe ritual is an implementation of the hadith of the Prophet Muhammad about reading bismillah to start a job. Abu Hurairah's hadith about something good must be started with goodness, including basmalah with the hope of asking Allah to be granted blessings. 
This is in accordance with the hadith of Rasulullah SAW which means "Having told me al-Husein bin Abdullah al-Qatan he said he had told us Hisham bin Ammar he said he had told us Abdul Hamid bin Abu 'Isyrin he said he had told us al- Auza'i from Qurrah from aj-Juhri from Abu Salamah from Abu Hurairah he said he had said the Messenger of Allah: "Every matter which has an interest, does not start with it with حصدِ التَّهِ then it is cut off!"

Second, perform the sungkeman ritual, which is respect for both parents by bowing your head and asking for blessings. This is in accordance with the results of an interview with Sugiyati that "this sungkeman is a farewell to both parents to ask for blessings to the parents so that the household will last. Before the bridal shower is given a cinde cloth, which is a cloth with a floral pattern of batik ceplok, and given a bandana ornament and jasmine flower back cover. "

Triyanto explained the sungkeman procedure that "the bride and groom kneel or squat in front of their parents, to show the filial piety of the son and daughter to both parents and to ask for blessings."

This ritual process is in accordance with the Koran in the letter alIsra Verse 24. While the symbolic meaning is a sign of filial piety or defection of a child to parents who have raised him to adulthood, the child's request to the parents to forgive their mistakes and ask for prayers blessing so that in building a household ark can be happy and prosperous (sakinah, mawadah, warahmah). The groom takes off the keris which is a symbol of the strength he wears when he sungkeman, this has a symbolic meaning of respect for the parents, and no matter how great the rank or strength the child has, it cannot be shown in front of the parents.

Javanese ethics highly uphold or pays respect to elders, both in terms of speech and in terms of behavior. Squatting is a symbol of the embodiment of the young who must respect and submit to the older one. Do'a pangestu from parents is always expected by the child in order to get married. In the Islamic concept, Allah's blessing is the blessing of both parents. After that, the prospective bride and groom are guided and taken by her parents to the place that has been prepared.

Third, ngracik toyo or water from seven sources which is then mixed with three-colored flowers. The water for the spray is taken from seven 
flower-infused sources, which eventually become fragrant like a bride. Toya pamorsih or also known as Banyu Perwitosari, Perwito means holy and sari means the flower sown with sritaman flowers (roses, jasmine, and cananga). Triyanto explained that "water is taken from seven sources, namely water from the palace, water fighting (the meeting of two downstream rivers), various springs or old sources that never dry out, and mixing zam-zam water for Muslims."

According to Sugiyarti, taking water from seven sources is meant by many sources. It is hoped that the bride and groom will have a lot of luck in her household life. "Ngintun Tyo which is given three colored flowers (jasmine, rose, and cananga) or five colors of five colors," added February in his explanation of the purpose of adding flowers to the seven sources of water.

Fourth, dongo, which is a request for salvation made by religious figures, perias, or elders who usually perform prayers. This prayer hopes to ask for salvation and that the bride and groom are given salvation both in this world and in the hereafter. "Prayers for the bride and groom make up the purpose of opening the prestige of the bride and groom so that her facial aura is opened, the task of the makeup is given goodness and success and also prayers of congratulations," said Sugiyati.

Fifth, siraman, which is a ritual starting from the father doing three siraman, followed by the mother and the elders, grandmother, and an odd number of bude. Siraman in Javanese is siram which means sesuci (Pringgawidagda, 2006). Siraman also means cleansing of "body wadak", in every step of the procession of the siraman so that the bride and groom clean themselves and their hearts. Cleanse oneself from stains and sins as well as bad qualities, cleanses all distractions before consenting to qabul, and can start a new life in a clean and pure state. So that it is even more stable to get married. Siraman starts from parents, namely father and mother, followed by elder relatives who are usually odd seven or five.

This stage is the core stage of this series of siraman rituals. Triyanto explained "Siraman also means cleansing the body wadak. In every step of the procession, the bride and groom cleanse themselves and their hearts. Cleanse oneself from stains and sins as well as bad qualities, cleanses all distractions before consenting to qabul, and can start a new 
life in a clean and pure state. So that it is even more stable to get married.

Sugiyati added that "this siraman watering given souvenirs (towel, soap, and finger) is done by 7 people who are elderly or old whose marriages can not be widowers or rondo (separation from husbands)." February added that the watering process was also carried out by parents to remind the prospective bride and groom of the services of parents who have cared for her since childhood. This is in accordance with the word of Allah SWT in al-Qur'an surah al-Baqarah verse 222.

Sixth, sesuci or ablution, which is a sacred procession by performing ablution with water poured out by the father from the jug used for the siraman. "The father of the bride sprays the water and then uses it as purified, performing ablution to purify it," February said. In the pratolo jug made of earth, the father poured out the ablution water from the water pitcher. Then the jug was broken by the parents as a sign of breaking the child's prestige as an adult woman.

Seventh, it breaks the kendi Pratolo which is made of earth. In ancient times, kendhi was a traditional drinking tool made of burnt clay because in the past there were no plastic or glass teapots factories. "Breaking a jug (pratolo) made of the earth which is done by both parents after being used for ablution," said Triyanto. Sugiyati explained that breaking the kendhi done by the mother of the bride was meant to break the prestige of the bride. "Breaking the kendhi Pratolo, hopefully, the prestige is like a dreamed angel," February said. A pitcher (pratolo) made of earth (which means from the ground back from nothing to nothing, from God returning to God) to perform ablution or purification.

Eighth, pondhongan or carrying, which is after carrying out activities for the bride and groom to be carried by her father into the room. Sugiyati explained that this pondongan shows the last affection of a father for his daughter, who is soon being proposed to her future husband. "Bopongan (carrying) carried by his father to the friend's room," February said adding this explanation.

Ninth, change clothes according to the confession from the make-up that "The bride and groom change clothes that have been prepared after 
doing the siraman. Change clothes with sawitan clothes for the old people who nowadays can change to other clothes. " said Sugiyati.

Tenth, potong rikma, namely cutting the hair of the bride and groom done by both parents. This haircut is taken from three to seven hairs that are on the front, side, and back of the bride and groom. "Both parents cut a part of the prospective bride's hair which is taken from 3-7 strands of hair in the front and back and put it in the water prepared by the makeup," said Triyanto.

Related to this, Sugiyati added: "Pruning of rekmo is done by parents cutting three strands of hair that are inserted into Tembogo brass to remove the sengkolo for the make-up usually doing a scrap so that the make-up is good." February also added: "Trim rekmo or hair to remove sesuker or eliminate sukerto". Cutting some of the bridal hair means that hopefully the bride and groom will always remember the services of her father and mother. Like they cut their hair and have left them to have a family with their husbands so that other people don't find out about each other's badness or in other words, they can save each other's shortcomings.

Eleventh, tanam rikma is planting the hair of the bride and groom that had been cut earlier. The haircut is planted in the corner of the house of the prospective bride. "Hair that has been cut and put into the ground in the corner or front of the house of the bride and groom," said Triyanto. Sugiyati and Terbang added that this hair planting was intended to plant the ugliness and shortcomings of the prospective bride and groom. Planting records can also be interpreted as the grave of rikma, which means that everything ugly or secrets are planted deeply so that no one else knows.

Twelfth, pagas tumpeng is cutting tumpeng by both parents, especially the mother. "The two parents cut the rice in the shape of a tumpeng, usually decorated with various ubo rampe such as chilies, eggs, and other shoots to be given to the bride and groom." said Triyanto. "Pagas tumpeng cuts the tumpeng robyong and is used for the bride's pan," added Sugiyati.

Thirteenth is the pagas tumpeng, namely the tumpeng which has been cut by the parents and then fed to the prospective bride and groom. "Both 
parents provide food by feeding the last bride with great affection before wading through the household and giving wening or white drinking water as a sign of the end of the pan," said Triyanto. Furthermore, February also added that the bride and groom who were fed a piece of tumpeng by their mother showed that this was the last bribe a mother gave to her child before marriage. "Dulang friends pungkasan means that you want to be independent, not depending on your parents," explained February. This celebration also includes showing the last love of parents for the prospective bride and groom after becoming a new family. In connection with parental love, Allah SWT teaches us to always pray.

Fourteenth, adol dawet, namely the parents of the prospective bride and groom selling dawet to their families and guests. Dawet itself is a traditional Javanese drink made from a mixture of cendol, coconut milk, and sugar. Family members and guests who attended bought the dawet with money made from kereweng. "Both parents sell dawet together, then the money used for buying is made of kereweng or tile soil. The buyers are all guests, helpers, and neighbors," said Triyanto. Related to this dawet selling procession, Sugiyati explained. "Adol dawet, the mother holding Ceting, is carried with a cinde shawl which means to refuse the balak walking towards the adol dawet place with her father using an umbrella," he said. Selling dawet ayu as a form of gratitude to Allah symbolizes that to make a living, you have to work hard and work hard. This hard work activity is in accordance with al-Qur'an surah az-Zumar verse 39 .

Fifth, it is duwet, which is to calculate the results of the sale of the dawet earlier. The mother of the bride and groom carries a basket as a place for money from selling dawet. Father became husband, received payment. This means that men are indeed obliged to earn a living (support their family) and always protect their wives so that their wives are happy, peaceful, and peaceful in their lives. In accordance with what was conveyed by the source that "the mother of the bride and groom carries a basket as a place for the money from selling dawet and after selling the money is counted to be given to the prospective bride." said Triyanto. 
Sixteenth, simpen pedaringan, namely kereweng money obtained from selling dawet earlier is saved in a container that is used to store rice with the intention that the bride and groom are expected to be able to save for their future. "Money storage made of kreweng or clay (dodol dawet) in the pedaringan (savings are put into the rice savings in the room which is usually used to store rice)," said Sugiyati. Furthermore, February also added that the prospective bride and groom would be a person who likes to save money. This love of saving is also in accordance with what Allah SWT said in the Qur'an al-Isra 'verse 26.

This is a series of the siraman rituals carried out just before the wedding day or the qabul consent which uses Javanese customs.

\section{Conclusion}

The ritual of siraman in Javanese traditional wedding in Kedungjati has connotations, denotations, and myths as in the semiotic analysis of Roland Barthes. The siraman ritual has sixteen stages of the process, namely the installation of bleketepe as without the traditional siraman opening, sungkeman as a sign of a request for the blessing to parents and proof of filial piety to parents, ngracik toyo is sprinkled with flowers in the hope that the bride and groom will be fragrant, praying to Allah SWT, Siraman, namely pouring water on the bride and groom to remove stains and sins, and as sacred as ablution with a jug from the ground to remove hadas and impurity. Furthermore, the kendhi pratolo is broken by both parents as a form of opening the aura and prestige of the bride and groom, pondhongan or being carried by the parents as a form of affection, changing clothes to wear a wedding dress, trimming the bridal haircutting (pangkas rikma) as a symbol of removing balak and sukerto, tanam rikma. to bury deeply the shortcomings of the bride and groom, pagas tumpeng as a form of gratitude to Allah by always remembering it, the results of the two parents as a sign of last affection, adol dawet symbolizing life in this world must be willing to strive, it is duwit as a form of gratitude after trying and simpen pedaringan as a symbol of using money sparingly and being able to save for the future.

\section{Bibliography}

Amin, D. (2002). Islam dan Kebudayaan Jawa. Gama Media. 
Anasom. (2004). Merumuskan Kembali Interelasi Islam-Jawa. Gama Media.

Arikunto, S. (2002). Prosedur Suatu Penelitian: Pendekatan Praktik Edisi Revisi Kelima. Rineka Cipta.

Aziz, D. K. (2013). Akulturasi Islam dan Budaya Jawa. Fikrah, 1(2).

Azra, A. (1999). Konteks Berteologi di Indonesia. Paramadina.

Baidhawy, Z. (2002). Agama dan Pluralitas Budaya Lokal. Pusat Studi Budaya dan Perubahan Sosial Surakarta.

Baran, S. J. (2010). Introduction to Mass Communication: Media Literacy and Culture. McGraw-Hill.

Barthes, R. (1972). Mythologies. Noondy Press.

Bates, D. G. (1990). Cultural Antropology. Mc Graw-Hill.

Bratasiswara, H. (2000). Bauwarna: Adat Tata Cara Jawa. Yayasan Citra.

Budiman, K. (2011). Semiotika Visual: Konsep, Isu, dan Problem Ikonisitas. Jalasutra.

Endraswara, S. (2006). Falsafah Hidup Jawa. Cakrawala.

Hadi, A. M. W. (2006). Terjadi Kultural di Tubuh Umat Islam. Suara Muhammadiyah.

Hanafi. (2016). Multikulturalisme dalam al-Qur'an, Hadis, dan Piagam Madinah. Jurnal Kajian Keislaman, 3(2).

Hariwijaya. (2004). Tata Cara Penyelenggaraan Perkawinan Adat Jawa. Hanggar Kreator.

Hayakawa. (1974). Symbol: Dalam Wayne Austin Shrope Experiences in Communication. Harcourt Brace Jovanovich.

Herusatoto, B. (1997). Simbolisme dalam Budaya Jawa. Hanindita.

Hidayat, K. (2012). Agama Punya 1000 Nyawa. Noura Book.

Irmawati, W. (2013). Makna Simbolik Upacara Siraman Pengantin Adat Jawa. Indigenous, 2(1), 327.

Kholil, A. (2008). Islam Jawa, Sufisme dalam Etika dan Tradisi Jawa. UIN Malang Press.

Koentjaraningrat. (2000). Kebudayaan Jawa. Balai Pustaka.

Moelong, L. J. (2009). Metodologi Penelitian Kualitatif. Remaja Rosdakarya. 
Mulder, N. (1986). Kepribadian Jawa dan Pembangunan Nasional. Gajahmada University Press.

Muti'ah, A. (2009). Penyerapan Nilai-nilai Budaya Lokal dalam Kehidupan Beragama di Cirebon dalam Harmonisasi Agama dan Budaya di Indonesia. Balitbang Agama.

Ngationo, A. (2018). Peranan Raden Fatah dalam Mengembangkan Kerajaan Demak pada Tahun 1478-1518. Jurnal Kalpataru, 4(1).

Prabowo, D. P. (2003). Pengaruh Islam dalam Karya- karya R. Ng. Ranggawarsita. Narasi.

Pringgawidagda, S. (2006). Tata Upacara dan Wicara Pengantin Gaya Yogyakarta. Kanisius.

Purwadi. (2004). Tata Cara Pernikahan Pengantin Jawa. Media Abadi.

Roqib, M. (2007). Harmoni Budaya Jawa. Pustaka Pelajar.

Ruben, B. D. (2014). Komunikasi dan Perilaku Manusia. Rajawali Pers.

Said, M. (2015). A Study on the Acculturation of Islam and Local Culture Bungamale as a Local Culture of South Sulawesi. Journal of Islamic Civilization in Southeast Asia, 4(1).

Sobur, A. (2003). Semiotika Komunikasi. Remaja Rosdakarya.

Susanto, A. S. (1979). Pengantar Sosiologi dan Perubahan Sosial. Bina Cipta.

Susilo, A. (2019). Peran Raden Fatah Dalam Islamisasi di Kesultanan Demak. Jurnal Kebudayaan dan Sastra Islam, 19(1).

Sutawijaya, etc. (1990). Upacara Penganten Tatacara Kejawen. Aneka Ilmu.

Syam, N. (2005). Islam Pesisir. LKIS.

Syam, N. (2007). Madzhab-mandzab Antropologi. LKIS.

Wibowo, I. S. W. (2013). Semiotika Komunikasi (Aplikasi Praktis bagi Penelitian \& Skripsi Komunikasi). Mitra Wacana Media.

Widiana, N. (2015). Akulturasi Islam dan Budaya Lokal dalam Tradisi (Nyumpet) di desa Sekuro Kecamatan Mlonggo Kabupaten Jepara. Jurnal Ilmu Dakwah, 35(2).

Zoest, L. V. (1991). Fiksi dan Non Fiksi dalam Kajian Semiotika, Penerjemah Manoekmi Sardjo. Intermas. 